\section{International Scientific Journal Theoretical \& Applied Science}

\author{
p-ISSN: 2308-4944 (print) e-ISSN: 2409-0085 (online) \\ Year: 2015 Issue: 05 Volume: 25
}

Published: $30.05 .2015 \quad$ http://T-Science.org

\section{Viktoriya Dmitrievna Zabolotnikova \\ PhD student, \\ "Economy", 2nd year \\ Turan University, Kazakhstan \\ ms.santay@mail.ru}

SECTION 31. Economic research, finance,

innovation, risk management.

\title{
KEY ASPECTS OF DEVELOPMENT ISLAMIC FINANCE THE REPUBLIC OF KAZAKHSTAN
}

Abstract: This article discusses some of the theoretical and applied aspects of Islamic economic theory, marked differences of Islamic financing from traditional banking. The article describes the historical attitudes towards lending rate. The analysis of the specific conditions of the transactions. Marked obstacles for the development of Islamic finance in Kazakhstan. Proposals for the development of Islamic finance in Kazakhstan.

Key words: Islamic financial instruments, Islamic economy, Islamic banking, Islamic finance, Islamic financial institutions, financing, Islamic Development Bank, the Republic of Kazakhstan, state regulation.

Language: Russian

Citation: Zabolotnikova VD (2015) KEY ASPECTS OF DEVELOPMENT ISLAMIC FINANCE THE REPUBLIC OF KAZAKHSTAN. ISJ Theoretical \& Applied Science 05 (25): 19-29.

Soi: http://s-o-i.org/1.1/TAS*05(25)5 Doi: crossef http://dx.doi.org/10.15863/TAS.2015.05.25.5

\section{КЛЮЧЕВЫЕ АСПЕКТЫ РАЗВИТИЯ ИСЛАМСКОГО ФИНАНСИРОВАНИЯ В РЕСПУБЛИКЕ КАЗАХСТАН}

Аннотация: В данной статье рассмотрены некоторые теоретические и прикладные аспекты исламской экономической теории, выделены отличия исламского финансирования от традиционного банкинга. В статье раскрываются исторические особенности отношения к ссудному проценту. Проведен анализ специфических условий совершения сделок. Отмечены преграды для развития исламского финансирования в Республике Казахстан. Сформулированы предложения по развитию исламских финансов в Республике Казахстан.

Ключевые слова: исламские финансовые инструменты, исламская экономика, исламский банк, исламские финансы, исламские финансовые институты, финансирование, Исламский банк развития, Республика Казахстан, государственное регулирование, инвестиционный капитал.

Постановка проблемы. Финансовый кризис 2008-2010гг. выявил ряд проблем мировой финансовой системы, который привел к продолжающейся рецессии мировой экономики.

Если мы обратимся к некоторым факторам финансового кризиса, поразившего практически все капиталистические системы, то заметим, что ни один из факторов не свойственен политике, основанной на принципах, характерных для модели исламских финансов:

- чрезмерное кредитование: излишняя обремененность кредитами; потребительские отношения (покупка в рассрочку, субстандартное кредитование); сельскохозяйственный долг;

- непрозрачная финансовая безопасность: вводящие в заблуждение рейтинги (уровень безопасности ААА был присвоен обеспеченным закладными ценным бумагам, которые вообще трудно поддаются оценке);

- ошибки в управлении: искаженная система поощрения (выплата щедрых бонусов управляющим), в то время как акционеры страдают; слабый надзор (разрушенная система с разрозненной регуляцией); регуляторные ошибки (наращивание теневой банковской индустрии до 10 трлн. долл.; низкий уровень проверки перед подтверждением выдачи кредита) [1].

$$
\text { При этом формированию }
$$
несбалансированной финансовой системы способствовали ее основные постулаты: ограниченное регулирование рыночных отношений и достижение максимальной прибыльности. Основными причинами кризиса явились общее дерегулирование финансового 
рынка и чрезвычайный рост фиктивного капитала.

Появление новых финансовых инструментов и трансграничных институтов, находящихся вне рамок традиционной системы регулирования и надзора, привели к формированию огромного количества денежной массы, не обеспеченной реальными активами. Денежная масса, которая генерируется и аккумулируется за счет сложных схем, превратилась в некий виртуальный капитал, не соответствующий объему производства реального сектора экономики. Основная часть финансовых ресурсов утратила свое первоначальное качество - обеспечение оборота реальных товаров и услуг - и все более вовлечена в спекуляции на сырьевых рынках, что способствует возникновению критических дисбалансов в развитии мировой экономики. В этих условиях назрела необходимость создания стабильной финансовой системы, связанной с реальным производственным процессом и устойчивым денежно-товарным оборотом. Здесь особую роль приобретают исламские финансовые инструменты [2].

Определённая устойчивость исламских финансовых организаций в условиях мирового кризиса ликвидности, рост их активов, поиск альтернативных форм финансирования - всё это вызывает стремление многих правительств принимать меры для внедрения принципов исламского финансирования. Финансовые системы, основанные на исламских принципах, направлены на устранение оплаты и получения ссудных процентов во всех формах [3].

Именно это табу делает исламские банки и другие финансовые учреждения принципиально отличающимися от западных банков. При этом следует отметить, что запрещение ссудных процентов является всего лишь одним и ключевым аспектом исламских финансов, который в моральном смысле является базовым принципом в целях обеспечения социальной справедливости. Данный запрет исходит из свода религиозных норм и принципов - шариата (поарабски слово shari'a означает «путь к источнику»). Исламские финансы исходят из моральных принципов, ключевыми из которых являются различие между запрещённым (haram) и разрешённым (halal), в том числе запреты на процентный рост в результате ростовщических операций (риба), азартные игры и спекуляции (maysir), неопределённость (gharar) [4].

Исламская финансовая система представляет собой финансовую систему, не предполагающую взимание процента. Принципы исламского финансирования основаны на доверии, честности, справедливости, определенности и транспарентности между участниками сделки.
Актуальность развития исламского финансирования в Республике Казахстан обусловлена устойчивостью исламских финансовых организаций в условиях мирового финансового кризиса, необходимостью диверсификации источников финансирования, привлечением внешних долгосрочных инвестиций для реализации планов индустриального развития [5].

Анализ исследований и публикаций. Некоторые авторы, анализируя возможности исламской экономики и исламских финансов, в частности, рассматривают экономическую и финансовую систему арабских или даже мусульманских стран. Например, Н.В.Жданов в своей монографии «Исламская концепция миропорядка» утверждает, что несостоятельность исламской экономики можно проследить на примере Саудовской Аравии, где существует разрыв между теорией и практикой: многие банки в королевстве практикуют операции, ничем не отличающиеся от аналогичных операций в западных банках [6]. Подобное утверждение представляется некорректным, учитывая тот факт, что в Саудовской Аравии оперируют не только исламские банки. Один из упреков, который нередко адресуется исламской финансовой системе ее критиками преобладание нормативистского подхода. В самом деле, нередко в работах мусульманских ученых, посвященных исламской экономике и исламским финансам скорее можно отыскать ответ на вопрос «как должно быть?», а не на вопрос «что происходит?». Как известно, экономическая наука должна лишь описывать существующее положение вещей, не предлагая каких-либо оценок и рецептов по решению имеющихся проблем. Как позитивная наука, экономика объясняет систему распределения богатства в обществе, действие законов рынка и выдает прогнозы, чего можно ожидать в будущем.

Саудовский экономист М.У.Чапра, утверждает исламская экономика нужна лишь в том случае, если она способна ответить на вопросы, на которые не может дать ответ традиционная экономика [7].

Учитывая тот факт, что исламская финансовая система составляет основу исламской экономической модели, не вызывает сомнений, что решение целого ряда экономических задач будет адресовано прежде всего исламским финансовым институтам, в том числе и тех, которые в принципе не относятся к сфере финансов.

Некоторых экономистов, знакомящихся с основами исламской экономики, вводит в заблуждение значительное число правовых дефиниций в работах по указанной 
проблематике. Это неудивительно, поскольку первыми авторами, писавшими на тему исламской экономики, были как раз мусульманские юристы. И по сей день среди авторов, пишущих об исламской экономике, немало правоведов. Используя междисциплинарный подход, мусульманские авторы обращались к экономической проблематике в контексте других актуальных проблем современности: отношений правителя и подданных, мусульман и немусульман, исполнения верующими религиозных обязанностей и др. Данная особенность исламской экономической доктрины вполне органично вытекает из специфики мусульманского права, где отсутствует жесткое деление на отрасли, как в западных правовых системах, и где тесно переплетаются сугубо моральные (этические) и правовые вопросы.

В Новейшее время первыми исследователями, уделившими внимание вопросам исламской экономики, также были не профессиональные экономисты, а политики: Хасан ал-Банна и Абу ал-Ала ал-Маудуди. Для них, как и для их предшественников, экономическое устройство по шариату также было идеалом, к которому необходимо стремиться. Опираясь на взгляды данных политических деятелей на экономические проблемы, некоторые критики исламской экономики делают выводы о тесной связи представителей фундаменталистских течений в исламе с исламскими финансовыми институтами. Вот, в частности, что пишет американский профессор Тимур Куран, в чьих словах сконцентрированы основные обвинения, которые предъявляют исламской экономике еe противники: «Если исламская экономическая деятельность и стала источником социальной опасности, то причина кроется в ее политической силе, включающей в себя влияние на будущее экономической политики. Исламские компании предоставляют финансовую помощь фундаменталистским политическим партиям и организациям, пытающимся ограничить социальные, экономические и культурные отношения между мусульманами и немусульманами» [8].

Говоря об исламской экономике, важно понимать, что речь идет не о формулировании каких-то особых законов экономического развития, а лишь об альтернативных методах ведения хозяйства, в основе которых лежат воззрения ученых из стран мусульманского Востока. Исламские финансовые институты являются частью современного мирового хозяйства и подчинены тем же экономическим законам, что и традиционные (неисламские) участники финансового рынка. Вместе с тем в рамках существующих законов как экономических, так и собственно юридических исламские финансовые институты предоставляют всем желающим возможность воспользоваться финансовыми продуктами, структурируемыми на альтернативной проценту основе. Некоторые исследователи ошибочно ставят знак равенства между исламской и беспроцентной финансовыми системами. Однако это утверждение является серьезной методологической ошибкой. Об исламской финансовой системе можно говорить лишь там, где применяются исламские методы финансирования. Существование же беспроцентной финансовой системы, как правило, обусловлено неразвитостью финансового сектора. По мере его развития беспроцентный характер экономики исчезает [8, 9]. Существует целый ряд исследований, авторы которых, исходя из тезиса о невозможности в современном мире финансовых отношений без ссудного процента в любых его формах, ставят вопрос о несоответствии методов финансирования, используемых исламскими банками и другими финансовыми институтами, шариатскому запрету ссудного процента. При этом сами авторы таких работ как правило не являются ни мусульманскими правоведами, ни светскими специалистами по мусульманскому праву [10].

В соответствии с наблюдением Роберта Мертона, исламские финансы увеличивают риски для остальной части глобальной финансовой системы, поскольку они менее понятны, чем традиционные финансы. Быстрое расширение исламской финансовой деятельности создает определенные ожидания у ее участников, что увеличивает возможности рисков, которые могут быть связаны с такой быстрой экспансией. Финансовая инновация часто приносит с собой изменения в восприятии риска. Мертон делает вывод, что «нечеткое понимание новой окружающей среды может создать ощущение большего риска, даже если объективный уровень риска в системе неизменен или уменьшен» [11].

Цель данной работы - попытаться разработать предложения по внедрению и восприятию исламских финансов как нового источника привлечения денег в Республике Казахстан. К тому же в Казахстане живут мусульмане, и их число с каждым днем растет, которые хотят вкладывать деньги по принципам шариата. Исламское финансирование даст возможность привлечь в экономику страны дополнительные неинвестируемые ранее средства.

Основные результаты. 1. «Исламский банк - это фактически торгово-инвестиционная компания, которая также занимается расчетами и денежными переводами. Понятие "кредит" в 
такой компании может быть только в одном значении - беспроцентный кредит, который выдается в ограниченных объемах на благотворительные цели. Остальные операции исламских банков - это совместный бизнес, проектное финансирование, торговое финансирование, аренда, авансовое финансирование, подряд и др. То есть, исламский банк непосредственно участвует в бизнесе, его доход связан с прибыльностью бизнеса, и он также несет риски, которые разделяют с ним его вкладчики - соинвесторы, открывшие в таком банке инвестиционные счета на основе принципа доверительного управления.

Сущность исламской экономики, прежде всего отказ от процента, отказ от фьючерсных сделок. Ближе всего как методика подходит понятие проектное финансирование. Проектное финансирование - это финансирование инвестиционных проектов, при котором источником обслуживания долговых обязательств являются денежные потоки, генерируемые проектом. Специфика этого вида инвестирования состоит в том, что оценка затрат и доходов осуществляется с учётом распределения риска между участниками проекта. Главная установка ислама, как метода определения подхода к объективному миру является - принципиальный запрет на игры со временем. Главная задача - не допустить игр со временем, а особенно не прожитого будущего времени. Для исламской экономики, в отличие от императора Веспасиана деньги «пахнут». К примеру, мы не можем пользоваться деньгами, полученными от продажи алкоголя, даже если этот алкоголь продан пьющим немусульманам, т.е мы не имеем права продавать алкоголь и пользоваться деньгами от проданного алкоголя. Динамика развития исламских банков эффективно конкурирует с динамикой развития обычных банков, многие европейские страны оценили преимущества работы с исламскими банками.

Основными принципами исламского финансирования являются - доверие, честность, справедливость, определенность и транспарентность между участниками сделки.

Отличительной чертой исламского финансирования является наличие совета по принципам исламского финансирования (Шариатский совет) при каждом исламском финансовом институте и проведении исламской финансовой операции. Шариатский совет существует для того, чтобы решать, соответствуют ли деятельность и операции исламских финансовых институтов принципам исламского финансирования.

В принципах исламского финансирования заложена прозрачность управления. То есть это этичный вид бизнеса, в котором меньше спекулятивных операций в отличие от традиционных методов финансирования.

Хотелось бы отметить, что исламское финансирование имеет некоторые отличия от традиционного банкинга, которые приведены в таблице 1.

Особенности исламского и традиционного банкинга.

Таблица 1

\begin{tabular}{|l|c|c|}
\hline \multicolumn{1}{|c|}{ Характеристика } & Исламский банкинг & Традиционный банкинг \\
\hline Процентная ставка & нет & есть \\
\hline Спекулятивное поведение & нет & нет \\
\hline Разделение риска & есть & низкая \\
\hline Направленность на реальный сектор экономики & высокая & низкая \\
\hline Социальная направленность & высокая & есть \\
\hline Право банка изменять условия договора & нет & \\
\hline
\end{tabular}

В целом, исламские финансовые отношения содержат следующие основные запреты:

- Риба (Riba - ростовщичество) - запрет на ссудный процент с долга, т.е. любой выплаты, превышающей предоставленный заем;

- Гарар (Gharar - неопределенность) - запрет на намеренный риск, выходящий за пределы необходимого, и неопределенность в контракте;
- Мейсир (Maisir - азарт) - получение прибыли в результате случайного стечения обстоятельств;

- Халяль (Halal) - запрет сделки, связанной с запрещенными видами деятельности (табачная, алкогольная продукция, оружие и боеприпасы, развлечения, азартные игры, предоставление финансовых услуг, противоречащих исламским финансовым принципам); 
- Бай ал-Кали би ал-Кали - продажа долга за долг, например, продажа форвардного контракта с отсрочкой платежа за него.

Вместе с тем согласно шариату поощряется взаимовыгодная торговля и инвестиции по принципу разделения как прибылей, так и убытков между участниками. Основные финансовые инструменты основаны на партнёрстве (musharaka и mudaraba) и на торговле (murabaha, ijara, salam). Основными источниками шариата являются Коран - священная книга, являющаяся Божьим Откровением, переданным архангелом Джабраилом (Гавриилом) пророку Мухаммеду, и Сунна - следование словам и поступкам пророка Мухаммеда. Исламские правила финансирования основаны на следующих религиозных особенностях запретах шариата.

Riba (риба) - получение или предоставление процента. Под «рибой» понимается доход, полученный от прироста стоимости и вознаграждения в виде процента за предоставленный займ. В западной банковской системе кредитор независимо от результатов деятельности заёмщика получает фиксированный возврат средств, в то время как исламские банки строят свою деятельность не на кредитных отношениях, а на основе инвестирования путём справедливого разделения прибыли и убытков. Учитывая, что прибыль нельзя гарантировать, исламские финансовые институты, инвестируя в проект, должны принять на себя часть риска в проекте. Таким образом, в рамках соблюдения социальной направленности финансирование на исламских рынках осуществляется на беспроцентной основе, проведение кредитных операций исламскими финансовыми институтами осуществляется в форме долевых участий, сдачи имущества, приобретённого ими для клиента.

Maysir (майсир) — спекулятивные и азартные сделки. Операции, основывающие на спекуляции и на усилии/действии сторон для получения дохода, включая любые виды деятельности, которые содержат любой элемент азартной игры, согласно нормам шариата считаются недействительными.

Gharar (гарар) - неопределённость в сроках завершения контракта или в предмете контракта, направленный запрет на продажу товара, которым не владеешь. Наличие неопределённости в договоре запрещается шариатом, так как это подразумевает событие, которое может не произойти. При заключении договора все стороны обязаны полностью раскрыть свои намерения и изложить всю информацию друг другу.

Таким образом, в основе вышеизложенных принципов исламского финансирования лежат религиозные нормы шариата, несущие в себе социальную направленность. Банки, действующие на исламских принципах, не используют один из основных источников прибыли обычных коммерческих банков (разницу между процентом по выданным ссудам и процентом по привлечённым средствам). Основной источник получения дохода для исламских банков состоит из других операций, не противоречащих шариату [5].

2. Если говорить о развитии исламских финансов в Казахстане, то следует отметить, что Казахстан на сегодняшний день выступил «пионером» среди стран СНГ и Центральной Азии по внедрению законодательной базы для развития исламского финансирования.

12 февраля 2009г. был подписан Закон «О внесении изменений и дополнений в некоторые законодательные акты по вопросам организации и деятельности исламских банков и организации исламского финансирования». В частности, в особенную часть Гражданского кодекса внесены изменения, устанавливающие возможность исключений из общих правил купли-продажи, доверительного управления. Кроме того, предусмотрено, что по договору банковского займа, по которому заимодателем выступает исламский банк, заём осуществляется на условиях срочности и возвратности и без взимания вознаграждения за пользованием деньгами.

Законы «О банках и банковской деятельности» и «Об инвестиционных фондах» дополнены нормой о статусе и порядке осуществления деятельности исламского банка и исламского инвестиционного фонда соответственно. В Закон «О рынках ценных бумаг» внесена новая глава «Особенности выпуска и обращения исламских ценных бумаг», a также изложены основные принципы исламского финансирования.

В 2011 году принят закон, предусматривающий возможность выпуска государственных исламских ценных бумаг, а также расширяющий перечень оригинаторов исламских ценных бумаг, выпускаемых резидентами Республики Казахстан. Правительством Республики Казахстан утверждена Дорожная карта развития исламского финансирования до 2020 года, реализация которой способствует созданию условий для стабильного развития индустрии исламских финансовых услуг, созданию критической массы эмитентов, инвесторов и участников рынка. В целях развития исламского финансирования, страхования и лизинга Национальным Банком Республики Казахстан разработан проект закона «O внесении изменений и дополнений в некоторые законодательные акты Республики Казахстан по вопросам страхования и исламского 
финансирования». На данный момент указанный законопроект находится на обсуждении в Парламенте Республики Казахстан [12].

В целом, согласно разработанному в АРД РФЦА (ныне Комитет по надзору и регулированию РЦБ НБ РК), проекту Плана действий по развитию исламских финансов в Казахстане на 2010-2020 годы, к 2020 году в республике, помимо 5 специализированных исламских банков, должны появиться исламские окна в 10 традиционных банках. Конечным же результатом реализации этой Дорожной карты должен стать ежегодный рост рынка исламских финансов на уровне $10-15 \%$, а также становление Алматы как регионального центра по исламскому финансированию и вхождение города в десятку ведущих финансовых центров Азии.

Таким образом, принятые изменения в законодательстве позволили Казахстану активно приступить к формированию исламской финансовой инфраструктуры в стране.

Вместе с тем, по мнению шариатского советника компании «Такафул» М.Каиргалиева, на сегодня для полноценного развития исламской финансовой системы в Казахстане, помимо исламского банкинга, необходимо активно развивать и другие сегменты исламского финансового рынка, такие как исламское страхование и развитие микрокредитных организаций [13].

В настоящий момент в Казахстане продолжается работа по совершенствованию законодательства.

3. Исламское финансирование в Казахстане все еще находится на начальном этапе развития: по в конце 2013 общий объем активов составлял менее \$200 млн. S\&P отмечает один исламский банк, активно работающий в этом направлении. Еще несколько финансовых компаний, выполняющих требования шариата (в том числе лизинговая компания, компания исламского страхования такафул и инвестиционный фонд), также имеют очень небольшой объем бизнеса в сегменте исламского финансирования [14].

Исламские финансовые институты в Республике Казахстан представлены:

1) АO «Исламский Банк «Al Hilal»;

2) Исламский Банк Развития;

3) $\mathrm{AO}$ «Fattah Finance», брокерская компания;

4) ОВС «Такафул» исламское страхование;

5) «Закят» фонд;

6) Учебно-аналитический центр по исламским финансам.

Первым исламским банк Al Hilal (OAЭ) открыт в марте 2010 года в соответствии с Соглашением между Правительством Республики Казахстан и Правительством Объединенных Арабских Эмиратов.
Приоритетные сектора для финансирования:

1) сельское хозяйство;

2) горнодобывающая и нефтяная промышленность;

3) торговля и услуги дистрибьютерств;

4) товары народного потребления;

5) строительство;

6) транспорт;

7) связь.

Деятельность банка в Казахстане пока охватывает корпоративный сектор, которому предоставляется полный перечень банковских услуг: финансирование, кредитование, консалтинговые услуги, операционное и кассовое обслуживание.

В розничном секторе банковские услуги включают в себя операционное обслуживание, а также депозитные услуги для VIP-клиентов. Исламский банк Al Hilal Bank сотрудничает с правительством РК при реализации крупных финансовых и инфраструктурных проектов.

Прибыль банка за 2013 год составила 419 млн. тенге. Текущий объем инвестиционного портфеля составляет около 110 млн. долл. США, по части портфеля банк занимает 28 позицию из 38 коммерческих банков Казахстана.

Исламский банк развития (ИБР) является единственным международным финансовым институтом в мире, который стал ориентиром для современных исламских банков. Банк является основным спонсором коммерческих исламских банков в мусульманских странах. Он был основан странами-участниками Организации исламской конференции 20 октября 1975 года. Банк учрежден с целью способствования экономическому развитию, социальному прогрессу и взаимного сотрудничества как странчленов ИБР и мусульманских сообществ, так и других стран в соответствии с принципами Шариата. Общий капитал ИБР составляет более 30 млрд. долл. США. Планируется к 2020 году довести капитал до 100 млрд. долл. США.

Деятельность ИБР в основном касается таких сфер, как развитие экономической и социальной инфраструктуры, содействие внешней торговли, оказание технической помощи. Приоритетными направлениями также являются поддержка малого бизнеса, развитие частного предпринимательства, финансирование региональных проектов.

К 2009 году каждый из банков страны (БТА, Казкоммерц, Халык, Нурбанк) привлек в среднем от 50 млн. до 150 млн. долл. США через ИБР в качестве агентов при финансировании казахстанских компаний посредством продукта мурабаха (договор купли-продажи)

В 2012 году ИБР сформировал заявки от казахстанских банков на открытие кредитной 
линии по торговому финансированию (мурабаха) на общую сумму до 100 млн. долл. США.

Средства, привлеченные традиционными банками, предназначены:

1) для развития собственных торговых операций;

2) для коммерческого кредитования отдельных видов бизнеса.

ИБР участвует в финансировании самого крупного в Казахстане транспортного проекта «Западная Европа - Западный Китай» (400 млн. долл. США). ИБР совместно с МИНТ разработана страновая карта (Membership Country Partnership Strategy - MCPS), которая предполагает инвестиции в Казахстан на сумму более 1 млрд. долл. США.

На сегодняшний день Акционерное Общество «Fattah Finance» занимает одно из главных мест среди компаний по предоставлению финансовых услуг в соответствии нормам Шариата. Благодаря большому количеству финансовых партнеров в районе Северной Африки, Ближнего Востока и Печерского Залива услуги выполняются достаточно качественно и выполняются в кратчайшее время. Организация предоставляет услуги по эмитенту насчет выпуска и размещения ценных бумаг, проводит консультации по государственной регистрации и перерегистрации ценных бумаг, а также разрабатывает инвестиционные решения в управлении портфелями ценных бумаг.

AO «Fattah finance» совместно с малазийской государственной компанией AmanahRaya создан исламский инвестиционный Хадж Фонд Казахстана, направленный на инвестирование сбережений населения, желающих совершить Хадж или Умру.

ОВС «Такафул» зарегистрирована в 2010 году. ОВС «Халалное страхование «Такафул» первая и единственная компания в Казахстане, предоставляющая услуги Исламского Страхования в соответствии с нормами и принципами Шариата.

Компания оказывает следующие виды услуг для физических лиц:

1) медицинское страхование лиц, выезжающих за границу;

2) страхование от несчастных случаев;

3) добровольное медицинское страхование.

Разделяются два вида такафула:

1) Общее (general) такафул страхование, подразумевает страховые программы (продукты), связанные с возмещением убытков по текущему состоянию имущества, принадлежащего страхователю и расходов по ответственности страхователя за действия перед третьими лицами.

2) Семейное (family) такафул страхование подразумевает страховые программы (продукты), связанные с возмещением убытков по текущему состоянию физического лица (держателя страхового полиса или иных выгодоприобретателей) или группы физических лиц (группы страхователей или иных выгодоприобретателей).

В 2011 году запущен новый исламский финансовый инструмент - Закят фонд Духовного управления мусульман Казахстана (без лицензии), являющийся распределительным центром для сбора закятных и благотворительных средств.

Выплата средств в Закят Фонд в Казахстане добровольна. Концепция Закят фонда основывается на модели Вакф, которая является одной из составляющих исламской экономической системы. Закят фонд мобилизует свободные ресурсы населения и обеспечивает их накопление в соответствии с принципами исламского финансирования.

Сущность вакф инструмента заключается в привлечении и аккумулировании имущества, переданного в качестве пожертвования, в фонде специального назначения с целью их коммерческого использования в интересах населения (как мусульман, так и немусульман) и государства.

12 марта 2014 г. Университет «Туран» при содействии Национального Банка Республики Казахстан, Ассоциации высших учебных заведений Республики Казахстан и Ассоциации финансистов Казахстана создал Учебноаналитический центр по исламским финансам. Деятельность центра направлена на осуществление научно-образовательной деятельности по реализации инновационных проектов и программ дополнительного и профессионального образования специалистов в области исламского финансирования [5].

4. Исламское финансирование может помочь Казахстану получить доступ к новому классу инвесторов, которые стремятся приобрести продукты, соответствующие нормам шариата. По данным $\mathrm{S} \& \mathrm{P}$, выпуски облигаций сукук эмитентов, домицилированных не в странах, входящих в Совет по сотрудничеству стран Персидского залива (Gulf Cooperation Council: Бахрейн, Кувейт, Оман, Катар, Саудовская Аравия, ОАЭ), а также не в Малайзии, вызывают значительную заинтересованность у инвесторов с Ближнего Востока и стран Азии, которые в среднем составляют около $60 \%$ всех инвесторов в эти инструменты. Кроме того, по оценкам S\&P, в 2014г. общий объем выпуска облигаций сукук в мире превысик \$100 млрд, что свидетельствует о высокой готовности инвесторов приобретать этот класс активов. Несмотря на некоторые негативные факторы, отмечаемые в 2014г., перспективы экономического роста в Казахстане в ближайшие годы как благоприятные. В стране 
выполняется большое число инвестиционных проектов, и Казахстан может использовать облигации сукук для привлечения внешнего финансирования. В частности, принцип обеспеченности активами, который используется в исламском финансировании (в соответствии с ним каждая финансовая операция связана с материальным идентифицируемым активом), делает облигации сукук привлекательными для финансирования проектов по развитию инфраструктуры.

Исламское финансирование может способствовать повышению уровня проникновения банковских услуг, который, по оценкам Всемирного банка, в Казахстане составляет около 40\%. В настоящее время в финансовой системе Казахстана работают 38 банков, обслуживающих примерно 17 млн человек, при этом 10 крупнейших банков контролируют около 80\% активов банковского сектора. Вместе с тем небольшим и средним банкам будет сложно конкурировать с более крупными финансовыми организациями. Увеличение линейки исламских финансовых продуктов может позволить банкам привлечь новых клиентов и осуществить стратегическое позиционирование бизнеса в банковской отрасли, которая характеризуется высоким уровнем конкуренции. Однако только этого будет недостаточно для стимулирования развития сегмента исламского финансирования.

Со временем исламское финансирование может обусловить повышение интеграции в регионе. Казахстан обозначил свои планы, согласно которым страна планирует стать центром исламского финансирования в СНГ. На взгляд S\&P, при условии значительных успехов в развитии исламского финансирования в Казахстане страна может стать платформой для этой отрасли в СНГ. Вместе с тем Казахстан может привлечь дополнительные иностранные капиталовложения от инвесторов, которые стремятся использовать эту страну в качестве плацдарма для расширения бизнеса в регионе.

5. Хотелось бы отметить, что исламское финансирование имеет как преимущества, так и недостатки:

Единственной проблемой выступает такой фактор, как незнание механизма функционирования исламских инструментов. К тому же необходимо разъяснить людям, что это не религиозная акция, а поиск альтернативной системы финансирования. В целом для страны это даст новый источник привлечения денег. К тому же в Казахстане живут мусульмане, и их число с каждым днем растет, которые хотят вкладывать деньги по принципам шариата. Исламское финансирование даст возможность привлечь в экономику страны дополнительные неинвестируемые ранее средства.

Казахстан не должен пытаться внедрить исламский банкинг, как это происходило в некоторых странах, быстро, рывком, за одну ночь. Необходимо это делать постепенно, не пропуская ни одного шага в становлении. Также очень важно иметь экспертов, разбирающихся в законах шариата, и профессионалов в исламском финансировании. И если страна пойдет именно по этому пути, то есть все шансы успешно внедрить исламский банкинг на своей территории.

Однако существуют определенные препятствия развития исламских финансов:

Во-первых, исламские финансы в их современном виде являются сравнительно молодой отраслью. Первые исламские банки получили лицензию чуть более 30 лет назад.

Второе, трудность при проведении трансграничных операций. Существуют значительные различия в структуре финансирования и документации различных стран.

В-третьих, несмотря на значительный прогресс, достигнутый в последние годы в создании нормативной базы для финансирования по шариату, все еще существуют пробелы, которые должны быть заполнены, особенно это касается вопроса управления ликвидностью, и в этом направлении регуляторы предпочитают иметь дело с традиционными финансовыми системами.

В-четвертых, одним из основных препятствий для развития исламского финансирования является отсутствие инструментов, позволяющих банкам обеспечивать эффективное управление ликвидностью. В некоторых случаях исламским банкам приходилось вкладывать избыточные денежные средства в активы, которые более ликвидны, но имеют низкую доходность, или в менее ликвидные инструменты с более высокой доходностью, но и более высоким риском. Центральный банк Малайзии решил этот вопрос, став крупнейшим эмитентом краткосрочных облигаций сукук в национальной валюте, которые банковская система использовала для управления ликвидностью, заменив ими продукты с более низкой маржой или более высоким риском. В 2013 Центральный банк Малайзии выпустил краткосрочные облигации сукук в ринггитах общим объемом около $\$ 50$ млрд. и стал крупнейшим в мире эмитентом таких облигаций.

Одним из главных недостатков исламских банков является их закрытость, это вызывает недоверие со стороны пользователей услугами 
банка и создает ассоциацию с терроризмом и экстремизмом.

6. По мере развития отрасли исламского финансирования одним из препятствий для будущего роста может стать конкуренция банков за привлечение и удержание наиболее квалифицированных сотрудников. Для снижения этого риска некоторые страны (в частности Франция и Великобритания) начали инвестировать средства в обучение следующего поколения специалистов по исламскому финансированию.

В 2012 году постановлением Правительства РК была утверждена «Дорожная карта развития исламского финансирования до 2020 года». Данный документ включает в себя восемь основных направлений: совершенствование законодательства; проведение информационноразъяснительной работы; развитие исламской финансовой инфраструктуры; развитие международного сотрудничества; развитие государственного сектора; развитие рынка исламских финансовых услуг; научнообразовательная работа и работа с инвесторами. В рамках седьмого направления «Научнообразовательная работа» предусмотрено включение дисциплины «Основы исламских финансов» в компонент по выбору для студентов экономических специальностей.

В ряде вузов страны уже ведется подготовка по данной дисциплине. В основном, в качестве рекомендуемой литературы предлагаются российские и зарубежные работы. В связи с этим студенты, свободно владеющие английским языком, не будут иметь проблем с поиском литературы. Действительно, зарубежными учеными разработано огромное количество работ, раскрывающих всецело теорию и практику исламского финансирования. Вместе с тем, в силу ряда объективных причин (отсутствие отечественных специалистов, новизна научной тематики, слабый общий уровень владения иностранных языком и т.д.) изучение основ исламского финансирования может вызвать значительные затруднения.

На сегодняшний день, после пяти лет с момента принятия отраслевого законодательства, сохраняется дефицит качественной соответствующей литературы на русском и, особенно, на казахском языке. Интернет стал основным источником знаний, порой субъективных. Кроме того, в работах отдельных исследователей встречаются неточности и ошибки, вводящие в заблуждение читателя. В частности, нередко встречается сравнение исламских ценных бумаг, являющихся имущественными сертификатами, с долговыми облигациями, что является серьезной ошибкой; часто акцентируется внимание на множестве арабоязычных терминов и неясно передается суть практических финансовых механизмов; также несправедливо распространяется мнение об их неприемлемости в местных экономических условиях [2, 6-10].

Исходя из выше перечисленного представляем возможным вводить курс «Основы исламских финансов» для студентов ВУЗов Республики Казахстан. Основные разделы рабочей программы должны включать такие вопросы как:

1. Этнокультурные цивилизационные истоки исламских подходов к общественно производственным отношениям;

2. Концепция «исламская экономика» как явление, находящееся в стадии формирования;

3. Основы исламских финансов и отличие исламского финансирования от традиционного;

4. Исламские финансовые инструменты;

5. Государственное регулирование рынка исламских финансов;

6. Зарубежная практика внедрения, развития и регулирования исламского финансирования.

Все эти разделы представляют собой базисную основу для разработки учебнометодических пособий. В рамке каждого раздела целесообразно рассматривать отдельные конкретные элементы, вопросы и задачи.

К сожалению, пока не существует всемирно признанного органа по аккредитации учебных заведений, желающих открыть на своей базе какую-либо программу по исламским финансам. По этой причине многие организации, желая заработать на популярности нового направления учебы, зачастую не обращают внимания на качество предоставляемых услуг. На подобных программах слушатели получают поверхностное образование, которое невысоко ценится в бизнес сообществе, и выпускникам бывает тяжело найти работу в индустрии исламских финансов.

Выводы. Исламские банки в рамках глобализации становятся всё более признанными и конкурентоспособными. По мнению экспертов, за последние три десятилетия они очень быстро расширились, имея приблизительно 250 млрд. долларов США в активах и значительный темп роста в $10-15 \%$ в год. Понимая специфику и значение исламских методов финансирования, обычные финансовые институты всё более активно начинают сотрудничать с ними либо в области предоставления займов, либо посредством исламских отделов (или так называемых исламских окон).

Предпосылками развития исламского финансирования в Республике Казахстан явились:

1. необходимость снижения зависимости от одного источника финансирования; 
2. привлечение внешних долгосрочных инвестиций для реализации планов индустриального развития;

3. задействовать в экономике страны финансовые ресурсы населения, не использующихся по причине отсутствия исламского финансирования [16].

Даже после краткого обзора внесенных изменений в некоторые законодательные акты Республики Казахстан становится понятно, что внедрение в Казахстане исламского финансирования расширяет спектр финансовых услуг, а значит, позволяет не только крупным финансовым институтам, но и простым гражданам использовать новые возможности для вложения своих инвестиций и получения дополнительных доходов. Кроме того, исламское финансирование, конечно же, является инструментом привлечения инвестиционного капитала и крупных мировых участников исламской финансовой индустрии. Развитие законодательной основы исламского финансирования также сопровождается появлением новых участников рынка, потому что свою деятельность начинают осуществлять и консалтинговые, и брокерские компании, деятельность которых соответствует принципам исламского финансирования. При этом исламский банкинг будет существовать параллельно с имеющейся банковской системой Казахстана. То есть у клиентов банков, как у физических, так и у юридических лиц, будет оставаться право выбора между традиционным и исламским банкингом.

При этом в процессе исследования были выделены некоторые недостатки, например, расходящиеся интерпретации законов шариата, недостаток доступных данных относительно статистики функционирования исламских финансовых институтов и нехватка профессиональных участников рынка, хорошо разбирающихся и в исламских финансах, и в принципах шариата. Решение этих проблем может потребовать сотрудничества международных финансовых институтов и исламских финансовых организаций наднационального уровня, подобно AAOIFI и IFSB, которые могут облегчить обмен мнениями и выработать особые рекомендации.

Обобщив мнения специалистов также можно сделать вывод, что основной проблемой развития исламских финансов выступает такой фактор, как незнание механизма функционирования исламских инструментов. К тому же необходимо разъяснить людям, что это не религиозная акция, a поиск альтернативной системы финансирования.

Также специалисты сходятся во мнении, что остро ощущается нехватка квалифицированных преподавателей и качественных учебников, зачастую научная литературы труднодоступна для широкого круга читателей.

В целом полагаем, что в последующие годы объем операций в сегменте исламского финансирования в Казахстане будет постепенно увеличиваться. В этот период исламское финансирование дополнит существующие традиционные банковские предложения и станет еще одним способом удовлетворения финансовых потребностей страны.

Дальнейшее развитие данного исследования состоит в исследовании места и роли исламских финансовых институтов и инструментов в экономической и финансовой системах мусульманских и немусульманских стран, а также изучение потенциала указанных институтов и инструментов в деле решения актуальных задач экономического развития.

\section{References:}

1. (2010) Svyataya investitsiya. - Available: http://www.vedomosti.ru/newspaper/article/201 0/04/28/232802 (Accessed: 20.04.2015).

2. (2014) Osnovy eticheskikh (islamskikh) finansov: uchebnoe posobie / pod redaktsiey E.A.Baydaulet. - Pavlodar: Tipografiya Sytina, 2014. - $326 \mathrm{p}$.

3. Zabolotnikova VD (2014) Islamskoe finansirovanie $\mathrm{v}$ Kazakhstane: stanovlenie i perspektivy razvitiya.// Nauchno-prakticheskiy zhurnal «Tranzitnaya ekonomika» - 2014. - № 2. - pp. 94-104

4. Aryspaeva BK (2015) Razvitie islamskikh finansov V Respublike Kazakhstan. INITSIATIVY XXI VEKA Izdatel'stvo: Institut biznesa, psikhologii i upravleniya (Khimki) ISSN: 2073-4131 s. 67-70

5. Zabolotnikova VD (2014) Activities of Islamic Financial Institutions in the Republic of Kazakhstan.// Eastern European Scientific Journal (Gesellschaftswissenschaften): 
Düsseldorf (Germany): Auris Verlag - 2014. №3.- pp. 118-121.

6. Zhdanov NV (2003) Islamskaya kontseptsiya miroporyadka. - Moscow, 2003. - pp. 325.

7. Chapra MU (2001) What is Islamic Economics? — Jeddah, 2001. - pp. 51.

8. Kuran T (2008) Islamskaya ekonomicheskaya mysl' i islamskaya ekonomika // Khristianstvo i Islam ob ekonomike / Pod red. M.A.Rumyantseva, D.E.Raskova. - SPb., 2008. - pp. 298.

9. Bekkin RI (2008) Somalilend: besprotsentnaya finansovaya sistema // Problemy sovremennoy ekonomiki. — 2008. — № 4 (28). — pp. 243247.

10. Maksimov AA, Miloslavskaya TP (1982) Islamskie banki $\mathrm{V}$ stranakh Blizhnego i Srednego Vostoka // Islam V stranakh Blizhnego i Srednego Vostoka. - Moscow, 1982.- pp. 25-39.

11. Merton RK (2000) Nauka i sotsial'nyy poryadok // Lichnost', Kul'tura. Obshchestvo. - 2000. - T. II. - Vyp. 2
12. (2014) Natsional'nyy bank Respubliki Kazakhstan. Press-reliz № 98, December 26, 2014.

13. (2011) Kazakhstan: orientatsiya ne Zapad // Islamskie finansy i biznes v Rossii: Available: http://islamic-finance.ru/news/2011-01-31-814/ (Accessed: 20.04.2015).

14. (2015) Islamskoe finansirovanie pronikaet na rynok RK// Forbes Kazakhstan // Available: http://forbes.kz/ (Accessed: 20.04.2015).

15. Zabolotnikova VD, Abdulvalieva IS (2014) Neobkhodimost' vvedeniya kursa «Osnovy islamskikh finansov» $\mathrm{v}$ vysshikh uchebnykh zavedeniyakh Kazakhstana // Mezhdunarodnaya nauchno-prakticheskaya konferentsiya. Kul'tura, obrazovanie i nauka vo blago obshchestva. Mat-ly mezhdunarodnoy nauchno-prakticheskoy konferentsii. November 21, 2014, Almaty, Universitet "Turan" , pp.141144.

16. Zabolotnikova VD (2014) Razvitie islamskogo finansirovaniya v Kazakhstane// Doklad na internet-portale G-Global - 2014. 